\title{
Using the LibOUAL+ Survey to Inform Strategic Planning
}

\author{
Patricia Andersen and Christine Baker \\ Colorado School of Mines, USA
}

\begin{abstract}
The Arthur Lakes Library at Colorado School of Mines participated in an extensive strategic planning process in the spring of 2017 resulting in the development of a strategic plan for 2017-2020. The impetus for this planning process was the addition of seven new faculty and staff members, including a new university librarian. Strategic planning involved input from all library employees as well as library stakeholders (students, faculty, and university staff members). In February 2018, the library's assessment committee conducted the latest round of LibQUAL survey data collection. The library has participated in the LibQUAL survey every three to four years since 2003. Our focus with previous surveys had been to make improvements in the library based on survey comments. After reviewing the results and comments of the 2018 LibQUAL survey, committee members Patricia Andersen and Christine Baker observed that information gleaned from the survey data and comments could be connected to goals and objectives in the library's strategic plan. In-depth analysis of survey data and comments could be used to assess relevance and achievement of goals in the current plan and as a tool for developing future strategic plans.
\end{abstract}

The first step involved analyzing the LibQUAL data and utilizing a coding system for the comments. The authors chose to adapt Brown University Library's Methodology for Coding Qualitative Data (User

Comments). ${ }^{1}$ After the comments were categorized and the LibQUAL survey data analyzed, connections between the results and the strategic plan were identified. The next step entailed an in-depth examination of the library's strategic plan highlighting all components that related to data and comments from the survey.

We found that many of the comments (both positive and negative) linked directly to goals, strategies, objectives, and actions in the strategic plan. Most of the comments involved physical space and use of space (e.g., more study space/rooms or needs updating, etc.) and ambiance (e.g., too noisy, good natural light, etc.). The responses to the core questions for the library as place dimension are aligned with the comments. The library is currently advocating for a renovation and the results from this survey demonstrate that stakeholders agree with the need to improve library spaces and ambiance. Several stakeholders mentioned the need for renovating the existing space or building a new library, adding evidence to the library's advocacy efforts. Addressing other aspects of the strategic plan, the library recently acquired new resources and implemented new services prior to the 2018 LibQUAL survey. Survey data and comments indicated that these resources and services were both welcomed and well-publicized.

Strategic planning and LibQUAL survey results and comments can be used together to assess resources, services, and space in the library. 2018 LibQUAL survey results and comments support and validate the direction of our current strategic plan and can be used as an assessment method as we move forward with our plan and develop future strategic plans.

\section{Introduction and Background}

The Arthur Lakes Library at Colorado School of Mines (Mines), an applied science and engineering school with approximately 6,000 students, is the only library on the Mines campus. The library has held a LibQUAL survey every three to four years since 2003, with the most recent survey held in 2018 . While the LibQUAL survey gathers feedback from faculty, as well as graduate and undergraduate students, the undergraduate students are the heaviest users of the physical library and make up the largest number of respondents to the survey. The response rate for each user group ranged from $10 \%$ to $11 \%$.

In January 2017, a year prior to running the LibQUAL survey, the Arthur Lakes Library participated in an extensive strategic planning process resulting in the development of a strategic plan for 2017-2020. The impetus for this planning process was the addition of new faculty and staff members, including a new 
university librarian, as well as a newly created library faculty position for a scholarly communications librarian. Once the strategic plan was completed, an outreach and engagement librarian position was created in response to the library's goal of expanding outreach and engagement.

The library's strategic planning process began with the development of new mission, vision, and values statements. Library staff then conducted a Strengths, Weaknesses, Opportunities, and Threats (SWOT) analysis. Various assignments throughout the planning process involved gathering and sharing information among the library staff about current library trends, happenings, and renovations via literature reviews. Brown bag sessions were also held throughout the planning process inviting feedback from students, faculty, and university staff. The culmination of these activities provided the library with the information needed to set strategic goals. Once the overarching goals were established, each library staff member selected a goal based on interest, to flesh out strategies, objectives, and actions for the library's strategic plan. A review of the results allowed for final edits and updates. The library's new strategic plan was completed and implemented in May of 2017. ${ }^{2}$

The Arthur Lakes Library's seven strategic plan goals ${ }^{3}$ :

1. Enhance the user experience

2. Cultivate and strengthen information competencies

3. Dynamically respond to users' resource needs

4. Expand outreach and engagement

5. Become the campus nexus for scholarly communication

6. Commit to career development for all library staff

7. Formalize library development

An important aspect of any strategic planning process is assessing the relevance and effectiveness of the plan after it is in place. Is the library on the right track in addressing the needs of our users? Have we achieved our goals and objectives? To begin addressing these questions, two members of the library's assessment committee, Patricia Andersen and Christine Baker, formed a team to examine how LibQUAL survey core questions, local questions (developed with the strategic plan in mind), and attached survey comments could be used to assess relevance and achievement of the library's goals. The team observed that 2018 survey data and comments could be connected to initiatives in the strategic plan and used as a tool to assess relevance and achievement of goals in the library's current plan and as an effective tool for developing future strategic plans.

\section{Approach}

The first step involved analyzing the LibQUAL data and utilizing a coding system for the comments. Once the comments were categorized and the LibQUAL survey data analyzed, connections between the results and the strategic plan were identified. The next step entailed an in-depth examination of the library's strategic plan highlighting all components that related to data and comments from the survey.

Two tables were compiled. Table 1 shows how the five local questions in the LibQUAL survey correspond with strategic plan goals and Table 2 shows direct links between the LibQUAL core questions and strategic goals. 
Table 1.

\begin{tabular}{|c|c|}
\hline LibQUAL survey local questions & Library strategic plan goals \\
\hline 1. Accessing library resources from off-campus & $\begin{array}{l}\text { 1. Enhance the user experience } \\
\text { 3. Dynamically respond to users' resource needs }\end{array}$ \\
\hline $\begin{array}{l}\text { 2. An environment conducive to learning } \\
\text { through classes, events, and activities }\end{array}$ & $\begin{array}{l}\text { 1. Enhance the user experience } \\
\text { 2. Cultivate and strengthen information competencies } \\
\text { 4. Expand outreach and engagement } \\
\text { 5. Become the campus nexus for scholarly communication }\end{array}$ \\
\hline $\begin{array}{l}\text { 3. Contribution to the intellectual atmosphere } \\
\text { of the campus }\end{array}$ & 5. Become the campus nexus for scholarly communication \\
\hline $\begin{array}{l}\text { 4. Reliable mix of technology to help me } \\
\text { complete my work }\end{array}$ & $\begin{array}{l}\text { 1. Enhance the user experience } \\
\text { 3. Dynamically respond to users' resource needs }\end{array}$ \\
\hline $\begin{array}{l}\text { 5. The library keeping me informed about } \\
\text { library resources and services }\end{array}$ & $\begin{array}{l}\text { 3. Dynamically respond to users' resource needs } \\
\text { 4. Expand outreach and engagement } \\
\text { 5. Become the campus nexus for scholarly communication }\end{array}$ \\
\hline
\end{tabular}

The five local questions and corresponding Arthur Lakes Library strategic plan goals

The library recently introduced EZproxy in response to Goal 3. Dynamically respond to users' resource needs. Therefore, local question 1 was included despite its similarity to the first question in the LibQUAL survey's information control dimension: Making electronic resources accessible from my home or office. New librarian positions were added to address strategic plan initiatives and led to the inclusion of local questions 2, 3, and 5. Local question 4 was included to help gauge satisfaction with recent technology acquisitions and existing computing resources. 
Table 2.

\begin{tabular}{|c|c|}
\hline Library strategic plan goals & LibQUAL Survey core questions \\
\hline Goal 1. Enhance the User Experience & $\begin{array}{l}\text { Readiness to respond to users' questions } \\
\text { Employees who have the knowledge to answer users' questions } \\
\text { Employees who understand the needs of their users } \\
\text { Willingness to help users } \\
\text { Dependability in handling users' service problems } \\
\text { Making electronic resources accessible from my home or office } \\
\text { A Library website enabling me to locate information on my own } \\
\text { Printed materials I need for my work } \\
\text { Electronic resources I need } \\
\text { Easy to use access tools that allow me to find things on my own } \\
\text { Print and/or electronic journal collections I need for my work } \\
\text { Library space that inspires study and learning } \\
\text { Quiet space for individual activities } \\
\text { A comfortable and inviting location } \\
\text { A getaway for study, learning, or research } \\
\text { Community space for group learning and group study }\end{array}$ \\
\hline $\begin{array}{l}\text { Goal 2. Cultivate and Strengthen } \\
\text { Information Competencies }\end{array}$ & Community space for group learning and group study \\
\hline $\begin{array}{l}\text { Goal 3. Dynamically Respond to Users' } \\
\text { Resource Needs }\end{array}$ & $\begin{array}{l}\text { Making electronic resources accessible from my home or office } \\
\text { Printed materials I need for my work } \\
\text { Electronic resources I need } \\
\text { Easy to use access tools that allow me to find things on my own } \\
\text { Print and/or electronic journal collections I need for my work }\end{array}$ \\
\hline $\begin{array}{l}\text { Goal 4. Expand Outreach and } \\
\text { Engagement }\end{array}$ & Employees who understand the needs of their users \\
\hline \multicolumn{2}{|l|}{$\begin{array}{l}\text { Goal 5. Become the Campus Nexus for } \\
\text { Scholarly Communication }\end{array}$} \\
\hline $\begin{array}{l}\text { Goal 6. Commit to Career Development } \\
\text { for all Library Staff }\end{array}$ & $\begin{array}{l}\text { Employees who instill confidence in users } \\
\text { Giving users individual attention } \\
\text { Employees who are consistently courteous } \\
\text { Employees who have the knowledge to answer users' questions } \\
\text { Employees who deal with users in a caring fashion } \\
\text { Employees who understand the needs of their users } \\
\text { Willingness to help users } \\
\text { Dependability in handling users' service problems }\end{array}$ \\
\hline Goal 7. Formalize Library Development & \\
\hline
\end{tabular}

Arthur Lakes Library strategic plan goals and corresponding LibQUAL survey core questions

After the 2011 LibQUAL survey, a graphic representation was made to augment the radar graphs and present comparative data on the superiority mean for the core questions for the undergraduate, graduate, and faculty user groups. ${ }^{4}$ The purpose was to show administration and stakeholders improvements to our services. After completion of the 2018 LibQUAL survey, data sets from 2014 and 2018 were added to the graphic representation. Nine graphs were prepared displaying the core question superiority mean for each of the three LibQUAL dimensions by user group and tables were used to show the superiority mean of the 2018 core questions. The team compared the data from the last three surveys to show trends in answers to the 
core questions and to see if implementation of 2017 strategic initiatives may have positively impacted 2018 survey results.

Next, the 2018 survey comments were analyzed. A total of 703 LibQUAL survey respondents, 22 faculty, 73 graduate students, and 188 undergraduate students provided comments that were then exported into an Excel spreadsheet. The team adapted Brown University Library's Methodology for Coding Qualitative Data (User Comments) to manually code and categorize respondents' comments. Brown University's methodology organizes comments according to LibQUAL survey dimensions: affect of service, information control, and library as place. ${ }^{5} \mathrm{We}$ also opted to create one general category that encompassed both positive and negative comments of a more general nature, such as "I really like the library" or "thanks for doing this survey."

The number of both positive and negative comments were recorded within each category. All comments phrased as suggestions were recorded as negative within their appropriate category. If one comment addressed multiple categories, it was recorded in each of the relevant categories. Color-coding was utilized to emphasize comments involving electronic content and collections; outreach and engagement efforts; and specific references to building updates or a renovation, due to the library's investment of energy in strategic initiatives encompassing these areas.

The comments were also organized by user group (faculty, graduate students, and undergraduates) allowing the team to see which concerns were most important to each group. Once the comments were coded and tallied, connections to goals, strategies, objectives, and actions in the library's strategic plan were identified and highlighted. The highlighting allowed the team to quickly observe areas of the strategic plan that aligned and connected with survey data and comments. Highlighting also allowed the team to see areas of the strategic plan that were not addressed by the LibQUAL survey.

\section{Findings and Observations}

The review of the library's strategic plan and the LibQUAL survey data and comments revealed that there were many direct links between the strategic plan and the data collected during the survey. We expected to see links with the local questions because these questions were developed with the strategic plan in mind. Many of the core questions in the survey can also be linked to goals in the strategic plan. Table 2 lists the strategic plan goals and connections to the LibQUAL survey core questions.

The team looked at the graphic representations and related tables of the core question responses over the last three LibQUAL surveys to examine trends, particularly for the questions that addressed strategic plan goals. Each user group was examined by the LibQUAL dimensions: affect of service, information control, and library as place.

Many of the core questions in the affect of service dimension show progressive improvement over the last three surveys. There is a trend to give low ratings to the questions Employees who understand the needs of their users and Dependability in handling users' service problems that continued in 2018 with lower scores from undergraduates and faculty.

Graduate students give the highest ratings in 2018 for questions in the affect of service dimension except for Dependability in handling users' service problems. Faculty gave much higher ratings to Dependability in handling user service problems, but gave the lowest ratings over the last three surveys to Employees who understand the needs of their users. These survey questions link to the library's strategic plan Goal 1. Enhance the User Experience, Goal 4. Expand outreach and Engagement and Goal 6. Commit to Career Development for all library staff. 
Table 3. 2018 Superiority mean for Affect of Service questions

\begin{tabular}{|l|l|l|l|}
\hline Affect of Service Questions & Ugrads & Grads & Faculty \\
\hline Employees who instill confidence in users & 0.13 & -0.13 & 0.17 \\
\hline Giving users individual attention & 0.02 & -0.03 & 0.11 \\
\hline Employees who are consistently courteous & -0.17 & 0.39 & -0.4 \\
\hline Readiness to respond to users' questions & -0.06 & -0.14 & -0.17 \\
\hline Employees who have knowledge to answer user questions & -0.13 & 0.03 & -0.4 \\
\hline Employees who deal with users in a caring fashion & -0.04 & 0.15 & -0.22 \\
\hline Employees who understand the needs of their users & -0.5 & 0.11 & -1.31 \\
\hline Willingness to help users & -0.01 & -0.11 & -0.21 \\
\hline Dependability in handling users' service problems & -0.63 & -0.8 & 0.22 \\
\hline
\end{tabular}

In the information control dimension all three user groups give low scores for the question: Easy-to-use access tools that allow me to find things on my own. These questions relate to library's strategic plan Goal 1. Enhance the User Experience.

Table 4. 2018 Superiority mean for Information Control questions

\begin{tabular}{|l|l|l|l|}
\hline Information Control Questions & Ugrads & Grads & Faculty \\
\hline Making electronic resources accessible from my home or office & -0.76 & -1.26 & -1.25 \\
\hline A library website enabling me to locate information on my own & -0.83 & -1.06 & -1.43 \\
\hline Printed library materials I need for my work & 0.08 & -0.44 & -0.29 \\
\hline Electronic information resources I need & -0.4 & -0.94 & -0.96 \\
\hline Modern equipment that lets me easily access needed information & -0.84 & -0.32 & -0.82 \\
\hline Easy-to-use access tools that allow me to find things on my own & -1.06 & -1.22 & -1.69 \\
\hline Making information easily accessible for independent use & -0.63 & -1.18 & -1.45 \\
\hline Print and/or electronic journal collections I need for my work & -0.41 & -1.1 & -1.7 \\
\hline
\end{tabular}

In the library as place dimension the question Library space that inspires study has a low rating for undergraduates whereas the graduate students gave the lowest score to Getaway for study, learning, or research. Faculty indicate that Comfortable and inviting location and Community space for group learning and group study show the lowest ratings. These questions all relate to the library's strategic plan Goal 1. Enhance the User Experience, Strategy 1-3 Physical Space. 
Table 5. 2018 Superiority mean for Library as Place questions

\begin{tabular}{|l|l|l|l|}
\hline Library as Place Questions & Ugrads & Grads & Faculty \\
\hline Library space that inspires study and learning & -1.2 & -0.82 & -0.61 \\
\hline Quiet space for individual activities & -1.03 & -0.89 & 0.75 \\
\hline Comfortable and inviting location & -0.81 & -0.86 & -1.31 \\
\hline Getaway for study, learning, or research & -0.55 & -1.1 & 0.27 \\
\hline Community space for group learning and group study & -0.82 & -0.43 & -0.67 \\
\hline
\end{tabular}

An evaluation of the 2018 comments by LibQUAL survey dimension, using Brown University Library's Methodology for Coding Qualitative Data (User Comments), ${ }^{6}$ showed that most comments aligned with the library as place dimension followed closely by information control, with the least amount of comments aligning with the affect of service dimension.

Looking at specific comment categories within dimensions, the majority of faculty comments concerned the online content and customer service categories. Graduate students were equally concerned with online content, ambiance, and use, while most comments provided by undergraduates addressed use and ambiance. Customer service and access to computers and electrical outlets were also frequently referenced by undergraduates, but not to the same extent as comments referencing use and ambiance.

Brown University Library's coding methodology describes use as "references to how the user works and uses (or would like to work and use) the physical space. It is also used to refer to the overall quality of the work environment." ${ }^{7}$ This category includes references to physical space and renovations, as well as the organization and remodeling of space within the library building. Ambiance includes comments with "references to environment and atmosphere of the library, often an ambiguous emotional comment." ${ }^{8} \mathrm{We}$ also included comments referencing "quiet" or "noise" in this category.

The emphasis of undergraduate and graduate student comments on use and ambiance indicates that the library's space and atmosphere matter a great deal to students. While many students rated the library highly in these areas, more rated the library negatively (e.g., more study rooms, less noise, more designated quiet space, and more space to study and work both individually and in groups). Information from these comments connect to the library's strategic plan Goal 1: Enhance the User Experience, and especially to Strategy 1-3. Physical Space.

One of the objectives of Goal 1. Enhance the user experience is to "Develop a shared vision for a complete library renovation (Objective 1-3-1)." The Arthur Lakes Library has been advocating for a new library or renovation for years. A library Building Advisory Committee (BAC) consisting of several library staff as well as other members of campus formed to address this initiative. In an effort to help BAC members better understand the needs of our library users and to boost support for a new building or renovation, a Comments of Note for the BAC-LibQUAL+ $2018^{9}$ document was created. This document includes both direct quotes from the survey comments as well as summaries of comments that addressed specific issues relating to the building and space. More than 100 of the 283 comments addressed aspects of the library's building and physical space, with some suggesting a renovation or a new building.

LibQUAL survey comments can also be linked to the survey's local questions and, consequently, to strategic plan goals. For example, students noted that they appreciated the new scanner in the library as well as the new technology available for checkout (e.g., thermal cameras, small mobile projector) and would like to see the technology collection continue to grow. On the other hand, students noted the lack of technology in the 
study rooms, such as large screens for practicing presentations, and lack of available computers. Several students stated that they use other spaces on campus in order to access needed technology. These comments are connected to Local question 4. Reliable mix of technology to complete my work and can be tied to Goal 1. Enhance the user experience.

Comments addressing Goal 3. Dynamically respond to users' resource needs indicate that recently acquired resources have been noticed and are appreciated across all user groups, with undergraduates expressing the most satisfaction with the library's print and electronic collections. The comments also exposed gaps in the physical and electronic collections. Some comments included specific title or subject recommendations, while others did not elaborate on their resource needs. Comments relating to resource needs can be tied directly to Objective 3-1-4. Involve stakeholders and increase knowledge of and participation in collections. Finding ways to effectively engage our stakeholders in the library's collections process is a challenge and the library will continue to work toward accomplishing this objective.

Goal 4. Expand Outreach and Engagement involved the creation of a new faculty librarian position to promote library services, resources, and programming. Local question 5. The library keeping me informed about library resources and services is the only local question that received positive scores for both undergraduates and graduate students. This data, along with positive comments regarding new resources, technology, and services, seems to indicate that the library has made progress addressing strategic initiatives involving outreach and engagement.

Additionally, the large amount of customer service related comments seem to indicate that customer service is an important part of our users' overall library experience and that initiatives in this area, Goal 6. Commit to career development for all library staff, are worthwhile and relevant.

These are just a few examples of how the comments contributed valuable feedback that validates the current plan and will help inform the library's next plan. LibQUAL survey data and comments primarily address the following strategic plan initiatives: Goal 1. Enhancing the user experience; Goal 3. Dynamically responding to users' resource needs; Goal 4. Expanding outreach and engagement, and; Goal 6. Commit to career development for all library staff. Survey data and comments also provided some insight into users' needs concerning Goal 2. Cultivate and strengthen information competencies and Goal 5. Become the campus nexus for scholarly communications.

\section{Limitations}

Some of the services and resources that were evaluated through the local questions were very new; for example, EZproxy was introduced several months before conducting the survey. The data indicates that students were more aware of our new services than faculty. This is not surprising as students are informed of library services during instruction sessions and workshops.

Additionally, qualitative data can be open to interpretation. For example, if survey respondents comment that they cannot find specific journals via the library's website, it may be that the library does not subscribe to the journals or it may be that the respondents are having difficulty navigating the library's website and online resources. These issues require further exploration and will need to be addressed using other forms of assessment.

\section{Conclusions}

The LibQUAL survey results and attached comments corresponding to strategic plan initiatives have confirmed that the library is on the right track to understanding our users' needs, especially concerning library as place. Comments were particularly helpful in clearly identifying shortcomings of the building and its space and in providing a venue for the voice of our users. The data and comments also validated longstanding concerns of library staff regarding the building and its space. Addressing other aspects of the strategic plan, LibQUAL survey data and comments have been helpful in assessing the relevance and achievement of current goals and will be effective in reminding the library what is important to our users 
when developing our next strategic plan. Including the same local questions in our next LibQUAL survey will be beneficial in providing insight for the library's current and future strategic planning initiatives in the areas of information literacy, scholarly communications, and outreach and engagement. Inclusion of these questions will also allow the library to better understand whether initiatives in these areas have positively impacted our users over the next few years. Survey data and comments did not address all of the library's strategic initiatives and, as noted above, further information gathering and assessment methods will need to be explored.

Next steps include presenting our findings to the entire library staff as we prepare to assess the current strategic plan as a group and move into our next strategic planning process.

-Copyright 2019 Patricia Andersen and Christine Baker

1. Brown University Library LibQUAL+ User Assessment Group, Methodology.

2. Arthur Lakes Library, Arthur Lakes Library: Mission.

3. Arthur Lakes Library, Arthur Lakes Library: Mission.

4. Lisa Dunn, "Focusing on the library.

5. Brown University Library, Methodology.

6. Brown University Library, Methodology.

7. Brown University Library, Methodology.

8. Brown University Library, Methodology.

9. Brianna Buljung, "Comments of note for the BAC."

Bibliography

Arthur Lakes Library. Arthur Lakes Library: Mission, Vision, and Values, 2017-2020 Strategic Plan. Golden, Colorado: Arthur Lakes Library, 2017. https://3a2vzv37nkuw3esf6a3u2t7s-wpengine.netdnassl.com/library/wp-content/uploads/sites/64/2017/12/Arthur-Lakes-Library-Strategic-Plan-objectiveVersion.pdf

Arthur Lakes Library. "Strategic Plan.” Last modified May 1, 2017. https://www.mines.edu/library/strategic/

Association of Research Libraries/Texas A\&M University. LibQUAL+2018 Survey: Colorado School of Mines. Washington, D.C.: Association of Research Libraries, 2018.

Association of Research Libraries/Texas A\&M University. LibQUAL+2014 Survey: Colorado School of Mines. Washington, D.C.: Association of Research Libraries, 2014.

Association of Research Libraries/Texas A\&M University. LibQUAL+ 2011 Survey: Colorado School of Mines. Washington, D.C.: Association of Research Libraries, 2011.

Brown University Library LibQUAL+ User Assessment Group. Methodology for Coding Qualitative Data (User Comments), Brown University library LibQUAL + Survey 2005: Summary of Findings and Analysis. Providence: Brown University Library, 2005. http://www.libqual.org/documents/admin/BrownU_2005_LQ_qual_method.pdf

Buljung, Brianna. “Comments of note for the BAC-LibQUAL+ 2018." Handout, Golden, Colorado, 2018.

Dunn, Lisa. "Focusing on the Library, Pt. 3: LibQUAL." Presentation, Golden, Colorado, 2013.

Shorb, Stephen R., and Lori Driscoll. "LibQUAL+ Meets strategic planning at the University of Florida." In Libraries Act on Their LibQUAL+ Findings : From Data to Action, edited by Fred M. Heath, Martha Kyrillidou, and Consuella A. Askey. Binghamton: Haworth Information Press, 2004, 173-180. 